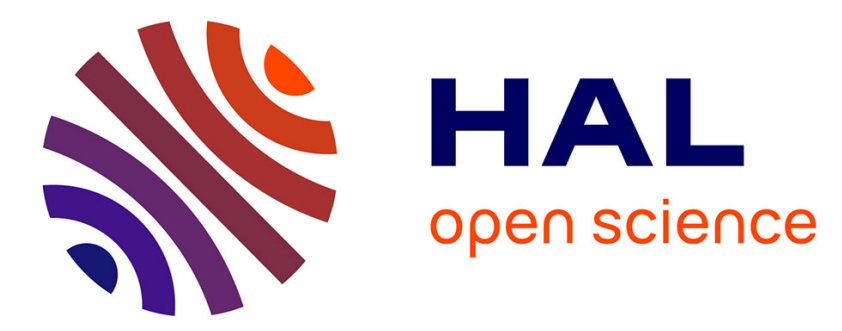

\title{
Corrosion Resistant Electrospun Niobium Carbide Nanotube Supports for PEMFC Cathodes
}

\author{
Y Nabil, S Cavaliere, I.A. Harkness, G. A. Hards, J. S. Sharman, Deborah
}

Jones, J Rozière

\section{- To cite this version:}

Y Nabil, S Cavaliere, I.A. Harkness, G. A. Hards, J. S. Sharman, et al.. Corrosion Resistant Electrospun Niobium Carbide Nanotube Supports for PEMFC Cathodes. ECS Transactions, 2015, 69 (17), pp. 1221-1226. 10.1149/06917.1221ecst . hal-01252813

\section{HAL Id: hal-01252813 \\ https://hal.science/hal-01252813}

Submitted on 8 Jan 2016

HAL is a multi-disciplinary open access archive for the deposit and dissemination of scientific research documents, whether they are published or not. The documents may come from teaching and research institutions in France or abroad, or from public or private research centers.
L'archive ouverte pluridisciplinaire $\mathbf{H A L}$, est destinée au dépôt et à la diffusion de documents scientifiques de niveau recherche, publiés ou non, émanant des établissements d'enseignement et de recherche français ou étrangers, des laboratoires publics ou privés. 


\title{
Corrosion Resistant Electrospun Niobium Carbide Nanotube Supports
} for PEMFC Cathodes

\author{
Y. Nabil ${ }^{\mathrm{a}}$, S. Cavaliere ${ }^{\mathrm{a}}$, I. A. Harkness ${ }^{\mathrm{b}}$, G. A. Hards ${ }^{\mathrm{b}}$ J. S. Sharman ${ }^{\mathrm{b}}$,D. J. Jones ${ }^{\mathrm{a}}$, J. \\ Rozière ${ }^{\mathrm{a}}$, \\ a ICGM -Agrégats Interfaces et Matériaux pour l'Energie, UMR 5253 CNRS, Université \\ de Montpellier, 34095 Montpellier Cedex 5, France \\ b Johnson Matthey Fuel Cells Ltd, Blounts Court, Sonning Common, Reading, Berks, \\ RG4 9NH, UK
}

\begin{abstract}
A synthesis route is reported based on the electrospinning technique that leads to $\mathrm{NbC}$ nanotubes with the appropriate properties for an electrocatalyst support for PEMFC cathode. The $\mathrm{NbC}$ nanotubes were successfully catalysed with $3 \mathrm{~nm}$ Pt particles by a microwave assisted polyol method so as to be investigated as electrocatalyst support. The accelerated stress test (AST) described in this contribution highlights the high stability of the novel $\mathrm{NbC}$ based support in comparison with a commercial $50 \% \mathrm{Pt} / \mathrm{C}$ with similar the electrochemical surface area (ECSA).
\end{abstract}

\section{Introduction}

Proton exchange membrane fuel cells (PEMFC) are promising energy conversion devices ${ }^{1}$. However, to facilitate their widespread adoption, several issues remain, such as the stability of the cathode to oxidation on high potential excursions, which needs to be significantly improved ${ }^{2,3}$. In some fuel cell operation conditions, carbon black electrocatalyst supports suffer from corrosion, leading to the aggregation, migration and detachment of electrocatalyst nanoparticles resulting in a loss of performance ${ }^{4,5}$. Recent research has shown that metal carbides including niobium carbide can present the required properties in term of electrical conductivity and stability in acidic media to replace the electrocatalyst supports conventionally used in $\mathrm{PEMFC}^{6,7}$. One of the remaining challenges is to design a support material with a morphology that will provide high surface area and adapted porosity ${ }^{8,9}$. Electrospinning ${ }^{10}$ is a simple and versatile technique for the elaboration of $1 \mathrm{D}$ nanostructures that have demonstrated unique electrical properties and high specific surface area ${ }^{11}$ promoting both high platinum dispersion and gas accessibility. An innovative composition and controlled morphology are both keys for increasing the stability and the performance of the catalyst support.

We describe here the elaboration of $\mathrm{NbC}$ nanotubes obtained by electrospinning, and their catalysation with platinum nanoparticles through a microwave assisted polyol method $^{12}$. The electrocatalytic activity, the electrochemical surface area (ECSA) and its stability as assessed by accelerated stress test (AST) are reported and compared to those of a commercial $50 \% \mathrm{Pt} / \mathrm{C}$. 


\section{Experimental}

Synthesis of $\mathrm{NbC}$ nanotubes

$1.8 \mathrm{~g}$ of ammonium niobate oxalate (ANO) $\left(\mathrm{NH}_{4}\right)_{3}\left[\mathrm{NbO}\left(\mathrm{C}_{2} \mathrm{O}_{4}\right)_{3}\right] \cdot 2 \mathrm{H}_{2} \mathrm{O}$ were dissolved in $5 \mathrm{~g}$ of distilled water and mixed with $4 \mathrm{~g}$ of ethanol containing polyvinylpyrrolidone (PVP, Mw 1,300,000, Aldrich). The ANO/PVP composite fibres were prepared by electrospinning the solution at $15 \mathrm{kV}$ and at a flow of $0.2 \mathrm{~mL} / \mathrm{h}$. The collected ANO-PVP composite fibres were heated in air at $600{ }^{\circ} \mathrm{C}$ for $3 \mathrm{~h}$ to remove the carrier polymer. The resulting $\mathrm{Nb}_{2} \mathrm{O}_{5}$ fibres were then heated at $1100{ }^{\circ} \mathrm{C}$ in $10 \% \mathrm{CH}_{4} / \mathrm{H}_{2}$ at a flow rate of $100 \mathrm{~mL} / \mathrm{min}$.until $\mathrm{Nb}_{2} \mathrm{O}_{5}$ was totally converted to $\mathrm{NbC}$, determined by monitoring the successive reactions ${ }^{13}$ with the TCD signal of a Micromeritics ASAP 2010 Chemi System.

\section{Characterisation of $\mathrm{NbC}$ nanotubes}

The sample morphology was characterised by scanning electron microscopy using a FEI Quanta FEG 200 SEM and by transmission electron microscopy using a JEOL 1200 EXII TEM. Powder X-ray diffraction (XRD) patterns were recorded at room temperature in Bragg-Brentano configuration using a PANAlytical $X$ 'pert diffractometer, equipped with a hybrid monochromator, operating with $\mathrm{CuK}_{\alpha}$ radiation $(\lambda=1.541 \AA)$, and using a step size of $0.1^{\circ} 2 \theta$ in the $2 \theta$ domain from 10 to $80^{\circ}$. Thermogravimetric analysis (TGA) using a Netzsch STA 409 PC apparatus was performed to determine the fraction of residual carbon contained in niobium carbide nanotubes. The residual carbon content was confirmed by CHNS elemental analysis.

\section{$\underline{\text { Pt particles synthesis and deposition }}$}

A microwave-assisted polyol method was used to synthesise $\mathrm{Pt}$ nanocatalyst particles ${ }^{12} .70 \mathrm{mg}$ of hexachloroplatinic acid $\left(\mathrm{H}_{2} \mathrm{PtCl}_{6} \cdot 6 \mathrm{H}_{2} \mathrm{O}, 99.9 \%\right.$ Alfa Aesar $)$ were dissolved in $50 \mathrm{~mL}$ of ethylene glycol (99.5\%, Fluka) and the $\mathrm{pH}$ adjusted to $\mathrm{pH} 11$ using $1 \mathrm{M} \mathrm{NaOH}$ solution (98\%, Sigma Aldrich) in ethylene glycol. The resulting solution was heated at $120{ }^{\circ} \mathrm{C}$ for 6 minutes in a microwave reactor (MiniFlow 200SS Sairem). A suspension containing $40 \mathrm{mg}$ of the $\mathrm{NbC}$ nanotubes in $5 \mathrm{~mL}$ ethylene glycol was added to the as-synthesised Pt nanoparticle suspension and the $\mathrm{pH}$ adjusted to 2 . After gentle stirring for 24 hours, the product was recovered by filtration, washed with milli-Q water and ethanol and dried overnight at $80{ }^{\circ} \mathrm{C}$. The loading of platinum (as measured by scanning electron microscopy - energy dispersive x-ray spectroscopy (SEM-EDX)) on the niobium carbide nanotubes (including any residual carbon) was 30 $\mathrm{wt} \%$. This value was confirmed by X-ray fluorescence (XRF) using a Panalytical Axios max with a $4 \mathrm{~kW}$ X-ray tube with $\mathrm{Rh}$ anode.

\section{Electrochemical characterisation}

The ex situ electrochemical analyses were carried out in a conventional threeelectrode cell consisting of a glassy carbon rotating disk electrode (RDE) (working electrode, geometric area of $0.196 \mathrm{~cm}^{2}$ ), a reversible hydrogen electrode (reference electrode, RHE) and a platinum wire (counter electrode). A Pine bipotentiostat model 
AFCBP1 was used. All the potential values are referred to the RHE. A catalyst ink was prepared using standard methods and the following materials: $10 \mathrm{mg}$ of $\mathrm{Pt} / \mathrm{NbC} ; 35 \mu \mathrm{L}$ Nafion (5\%) (Aldrich); $1 \mathrm{~mL}$ water (milli-Q water); and $4 \mathrm{~mL}$ isopropanol (Aldrich). 6 $10 \mu \mathrm{L}$ of the catalyst ink (depending on the Pt loading) were deposited onto the electrode to give $6 \mu \mathrm{g}_{\mathrm{Pt}} /$ electrode. Cyclic voltammetry was carried out at $50 \mathrm{mV} / \mathrm{s}$ in $\mathrm{N}_{2}$ saturated $\mathrm{HClO}_{4}(0.1 \mathrm{M}$ solution) and the electrochemical surface area (ECSA) of the platinum catalyst was calculated by integrating the peak corresponding to desorption of hydrogen from the Pt sites. An accelerated stress test (AST) was performed to investigate the stability of the catalysed supports by monitoring the ECSA over prolonged cycling. Cyclic voltammetry was carried out between $0.03 \mathrm{~V}$ and $1.2 \mathrm{~V}$ for 3000 cycles at 500 $\mathrm{mV} / \mathrm{s}$. Every 100 cycles, two cycles were performed at a slower rate of $50 \mathrm{mV} / \mathrm{s}$ and the ECSA calculated from them.

\section{Results and discussion}

Synthesis and physical characterisation

Composition: NbC was clearly identified as the only crystalline phase in the $\mathrm{X}$ ray diffraction pattern of the $\mathrm{NbC}$ nanotubes (Figure 1). The amount of residual carbon was investigated by thermogravimetric analysis via a calibration that links the mass variation with the $\mathrm{NbC} / \mathrm{C}$ ratio ${ }^{14}$; the proportion of the amount of residual carbon over the total amount of $\mathrm{NbC}$ and residual carbon was $4 \mathrm{wt} \%$. This residual carbon might be formed during the carburation by decomposition of $\mathrm{CH}_{4}$ at high temperature.

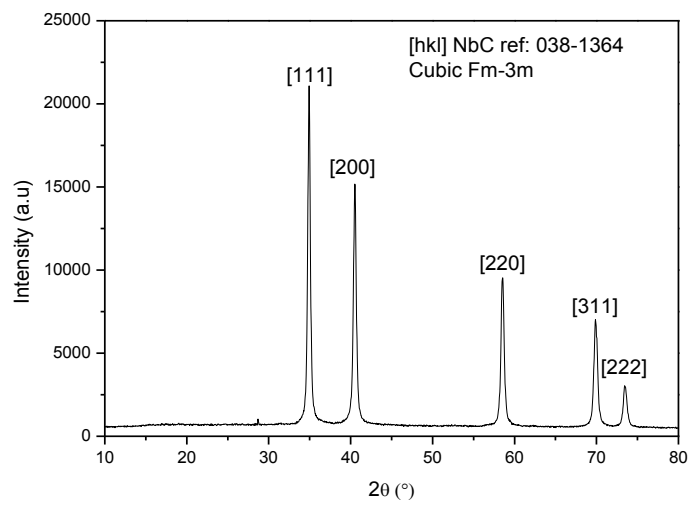

Figure $1 \mathrm{X}$-ray diffraction profile of the $\mathrm{NbC}$ nanotubes obtained after the carburation step.

Morphology: FEG-SEM (Figure 2) shows hollow 1D structures with porous walls, that could be an asset for the accessibility of the reactants to the catalyst ${ }^{3}$. An external average diameter of $160 \mathrm{~nm}$ for the nanotubes was measured. 


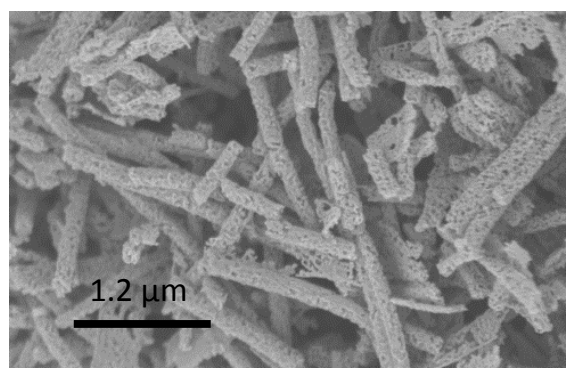

Figure 2 SEM micrographs of the $\mathrm{NbC}$ nanotubes.

\section{Electrocatalyst deposition}

Platinum particles were synthesised and deposited on the $\mathrm{NbC}$ nanotubes with a weight Pt loading of $30 \%$ (determined by SEM-EDX and XRF). A homogeneous dispersion of the particles with an average diameter of $3.1 \mathrm{~nm}$ was observed by TEM (Figure 3).

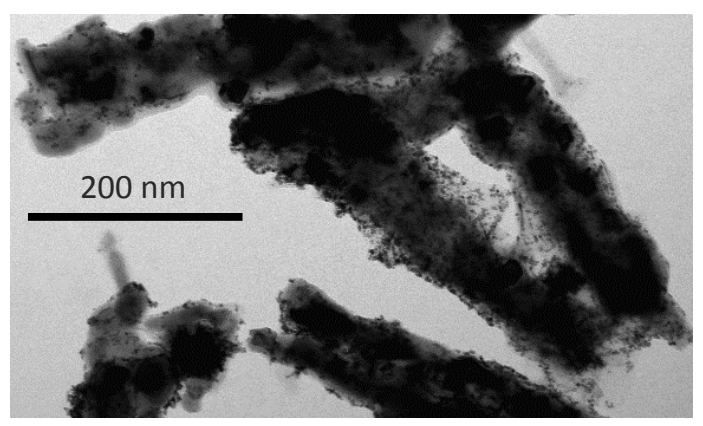

Figure 3 TEM micrograph of NbC nanotubes catalysed with Pt nanoparticles.

\section{Electrochemical characterisation}

Electrochemical characterisation was performed on $\mathrm{Pt} / \mathrm{NbC}$ nanotubes and 50 wt $\% \mathrm{Pt} / \mathrm{C}$ (Alfa Aesar) used as reference. Cyclic voltammetry was carried out at $50 \mathrm{mV} / \mathrm{s}$ in $\mathrm{N}_{2}$ saturated $\mathrm{HClO}_{4}(0.1 \mathrm{M}$ solution) and the electrochemical surface area (ECSA) of the platinum catalyst was calculated by integrating the peak corresponding to desorption of hydrogen from the Pt sites ${ }^{15}$ (Figure 4).

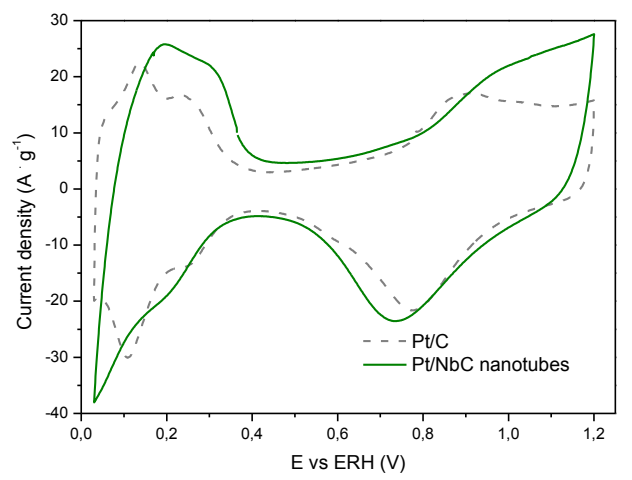

Figure 4 Cyclic voltammetry of $30 \% \mathrm{Pt} / \mathrm{NbC}$ supports and $50 \% \mathrm{Pt} / \mathrm{C}$ in $\mathrm{N}_{2}$ saturated $\mathrm{HClO}_{4}$. 
Cyclic voltammetry comprising 3,000 cycles up to $1.2 \mathrm{~V}$ was performed to investigate the stability of the catalysed supports, and the ECSA loss was evaluated ${ }^{16}$. The results are given in Figure 5 . The initial ECSA of the $30 \% \mathrm{Pt} / \mathrm{NbC}$ nanotubes was slightly lower than that of $50 \% \mathrm{Pt} / \mathrm{C}\left(43 \mathrm{~m}^{2} / \mathrm{g}\right.$ vs $\left.52 \mathrm{~m}^{2} / \mathrm{g}\right)$. However the $30 \% \mathrm{Pt} / \mathrm{NbC}$ nanotubes showed significantly greater stability to electrochemical corrosion since on voltage cycling to $1.2 \mathrm{~V}$ the ECSA was reduced by only $12 \%$, compared with a loss of $25 \%$ for the $\mathrm{Pt} / \mathrm{C}$. The decrease in ECSA can be explained by two simultaneous phenomena related to the catalyst and its support: platinum particles degradation (involving Pt detachment, Pt dissolution/reprecipitation and Oswald ripening) and the corrosion of the support (also involving catalyst detachment) ${ }^{17,18}$. Furthermore, a thin layer of $\mathrm{Nb}_{2} \mathrm{O}_{5}$ at the surface of the $\mathrm{NbC}$ nanotube sample was identified by XPS analysis $^{19}$; this oxide layer possibly protects the support from further oxidation. Further analyses are planned to study any eventual progression of the oxide towards the core of the material.

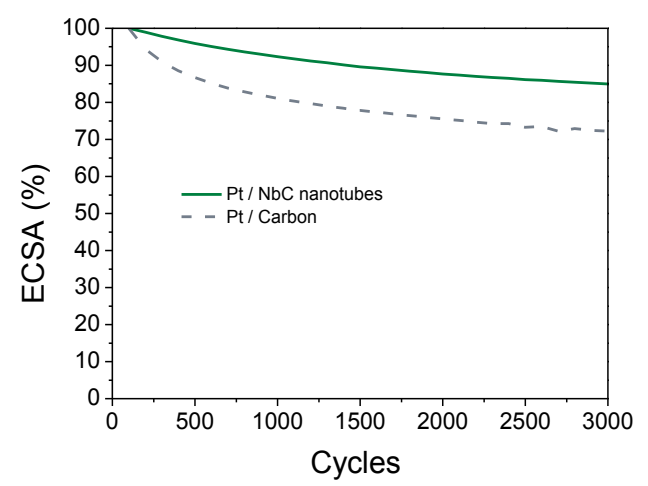

Figure 5 Stability of the ECSA of the catalysed supports during the accelerated stress test to $1.2 \mathrm{~V}$.

\section{Conclusion}

This work reports for the first time a synthesis route for the elaboration of niobium carbide nanotubes with porous walls. The support was catalysed with $3 \mathrm{~nm} \mathrm{Pt}$ particles using a microwave-assisted polyol method. The electrochemical characterisation through accelerated stress test of the supported platinum particles reveal that this novel support is highly stable compared to a commercial $50 \% \mathrm{Pt} / \mathrm{C}$ with similar ECSA. Further characterisation such as the in situ characterisation of this electrocatalyst support are planned to confirm this trend.

\section{Acknowledgments}

The financial support of Johnson Matthey Fuel Cells and the French CNRS through a $\mathrm{PhD}$ fellowship is acknowledged with thanks.

\section{References}

1. R. Makharia, S. Kocha, P. Yu, M. Sweikart, W. Gu, F Wagner and H. Gasteiger, ECS Trans., 1, 3-18 (2006). 
2. E. Antolini, Appl. Catal. B Environ., 88, 1-24 (2009).

3. S. Sharma and B. Pollet, J. Power Sources, 208, 96-119 (2012).

4. S. Maass, F. Finsterwalder, G. Frank, R. Hartmann, and C. Merten, J. Power Sources, 176, 444-451 (2008).

5. Y. Shao, J. Liu, Y. Wang, and Y. Lin, J. Mater. Chem., 19, 46-59 (2009).

6. Z. Qiu, H. Huang, J. Du, T. Feng, W. Zhang, Y. Gan, J. Phys. Chem. C, 117, 1377013775 (2013).

7. Y. Liu, T. G. Kelly, J. G. Chen, and W. E. Mustain, ACS Catal., 3, 1184-1194 (2013).

8. X. S. Zhou, Y. J. Qiu, J. Yu, J. Yin, and S. Gao, Int. J. Hydrogen Energy, 36, 73987404.

9. H. Liu, F. Wang, Y. Zhao, and H. Fong, Nanoscale, 5, 3643-3647 (2013).

10. S. Cavaliere, S. Subianto, I. Savych, D. J. Jones, and J. Rozière, Energy Environ. Sci., 4, 4761-4785 (2011).

11. M. S. Saha, V. Neburchilov, D. Ghosh, and J. Zhang, Wiley Interdiscip. Rev. Energy Environ., 2, 31-51 (2013).

12. I. Savych, S. Subianto, Y. Nabil, S. Cavaliere, D. Jones and J.Rozière, Phys. Chem. Chem. Phys., 17, 16970-16976 (2015).

13. V. L. S. Teixeira da Silva, M. Schmal, and S. T. Oyama, J. Solid State Chem., 123, 168-182 (1996).

14. J. B. d'Arbigny, G. Taillades, M. Marrony, D. J. Jones, and J. Rozière, Chem. Commun. (Camb)., 47, 7950-7952 (2011).

15. S. Gojković, S. Zečević, and R. Savinell, J. Electrochem., 145, 3716-3720 (1998).

16. S. N. Stamatin and E. M. Skou, ECS Trans., 58, 1267-1276, 10 pp. (2013).

17. A. Topalov, I. Katsounaros. M. Auinger, S. Cherevko, J. Meier, S. Klemm, K. Mayrhofer, Angew. Chem. Int. Ed. Engl., 51, 12613-5 (2012).

18. J. Meier, C. Galeano, I, Katsounaros, A. Topalov, A, Kostka, F, Schüth, K. Mayrhoder, ACS Catal., 2, 832-843 (2012).

19. M. T. Marques, A. M. Ferraria, J. B. Correia, A. M. B. Do Rego, and R. Vilar, Mater. Chem. Phys., 109, 174-180 (2008). 